\title{
DESTINATION BRANDING JEMBER PADA PEMBERITAAN JEMBER FASHION CARNAVAL 2016 DI MEDIA ONLINE
}

\author{
Muntadliroh \\ Humas Balai Konservasi Tumbuhan Kebun Raya Eka Karya Bali LIPI \\ Candikuning, Baturiti, Tabanan, Bali \\ No. Telp./HP: (0368) 2033211, 081390357572 \\ E-mail:mun_tadliroh@yahoo.com,munt001@lipi.go.id
}

Naskah diterima tanggal 23 Oktober 2016, direvisi tanggal 4 November 2016, disetujui tanggal 21 November 2016

\section{JEMBER DESTINATION BRANDING OF 2016 JEMBER FASHION CARNAVAL NEWS IN ONLINE MEDIA}

\begin{abstract}
The 2016 Jember Fashion Carnaval (JFC) has been widely reported in the online media from August to September 2016. This annual carnival provides implications on the effort of the Jember City destination branding. The purpose of this study is to analyze the news content of 2016 JFC on the online media from August to September 2016. The focus of this study is the interpretation of 2016 JFC news text that formed the destination branding of Jember City. This study applies content analysis method with the descriptive quantitative approach. The results of this study indicate that the news of 2016 JFC represents the development phase of Jember City destination branding with the most information source coming from bureaucrats (39\%), most news contents topic are 2016 JFC review (20\%) and 2016 JFC event (20\%), most news category theme is lifestyle, and dominated by positive news tone $(70 \%)$.
\end{abstract}

Keywords: Jember Fashion Carnaval, destination branding, conventional content analysis.

\begin{abstract}
Abstrak. Jember Fashion Carnaval (JFC) 2016 telah banyak diberitakan di media online selama bulan Agustus - September 2016. Karnaval tahunan ini memberikan implikasi pada upaya destination branding Kota Jember. Penelitian ini bertujuan menganalisis isi pemberitaan JFC 2016 di media online selama bulan Agustus - September 2016. Fokus penelitian ini adalah pemaknaan teks/pesan pemberitaan JFC 2016 yang membentuk destination branding Kota Jember. Metode yang digunakan adalah content analysis dengan pendekatan kuantitatif deskriptif. Hasil penelitian menunjukkan bahwa pemberitaan JFC 2016 merepresentasikan tahapan pembangunan destination branding Kota Jember dengan sumber informasi terbanyak dari birokrat (39\%), konten berita terbesar berisi topik review JFC 2016 dan penyelenggaraan JFC 2016 masing-masing sebanyak (20\%), kategori berita terbanyak bertema lifestyle (40\%), dan didominasi tone berita positif (70\%).
\end{abstract}

Kata kunci: Jember Fashion Carnaval, destination branding, analisis isi media.

\section{PENDAHULUAN}

Jember Fashion Carnaval (JFC) adalah event karnaval busana tahunan yang diselenggarakan di Kabupaten Jember, Jawa Timur. JFC pertama kalinya diinisiasi oleh Dynand Fariz sebagai pendiri JFC Center pada Tahun 2003. Pada Tahun 2016 
ini penyelenggaraan JFC memasuki etape ke-XV dengan mengusung tema "Revival" yang melambangkan kebangkitan Indonesia. Dalam perjalanannya, JFC hadir dengan menampilkan tema karnaval busana yang baru dan berbeda di setiap tahunnya.

Adanya nuansa tampilan yang berbeda dalam setiap penyelenggaraan JFC menjadi magnet penarik minat masyarakat untuk hadir dan menyaksikan pagelaran JFC setiap tahunnya. Hal ini sesuai dengan visi JFC yaitu menjadikan Jember sebagai kota wisata mode pertama di Indonesia dan dunia. JFC menjadi salah satu langkah yang dilakukan oleh masyarakat dan Pemkab Jember dalam memasarkan potensi wilayahnya dalam perspektif destination branding. Konsep destination branding didasari oleh passion dan identitas yang menarik yang saling berhubungan dengan berbagai hal yang akan memudahkan orang memiliki asosiasi dengan tempat tersebut (Situmorang, 2008). Melalui JFC, Jember telah mengelaborasi potensi dan keunggulan daerahnya yang tidak dimiliki oleh daerah lain.

Ketenaran JFC tidak terlepas dari keberhasilan publikasi melalui lini masa. JFC 2016 yang diselenggarakan dari tanggal 24-28 Agustus 2016 telah banyak diberitakan oleh media massa dari awal Agustus hingga awal September 2016. Di era digital, media online menjadi pintu utama penyebaran informasi berbasis internet. Hal ini sesuai dengan definisi media massa sebagai saluran-saluran atau cara pengiriman bagi pesan-pesan massa, media online merupakan bagian dari media massa, yaitu media massa yang tersaji secara online di situs web (website) internet (Romli, 2012).

Pertautan pemberitaan JFC 2016 dalam konteks destination branding Jember menarik untuk diteliti menggunakan pendekatan analisis isi media. Fokus penelitian ini adalah pemaknaan teks/pesan pemberitaan JFC 2016 yang membentuk destination branding Kota Jember. Melalui analisis isi media, dapat diketahui kecenderungan pemberitaan penyelenggaraan JFC 2016 khususnya yang diterbitkan oleh media online dan implikasinya terhadap destination branding Jember.

Secara praktis, hasil penelitian ini dapat menjadi rujukan bagi penyelenggaraan JFC dalam melakukan evaluasi JFC yang sudah berjalan dan perencanaan JFC pada tahun berikutnya agar lebih baik sebagai bagian dari upaya destination branding Kota Jember. Pemberitaan JFC 2016 melalui media massa online juga berdampak pada pembentukan persepsi dan realitas audiences terhadap JFC 2016.

\section{LANDASAN KONSEP}

Penelitian analisis isi media sudah banyak dilakukan, namun tulisan mengenai analisis isi pemberitaan Jember Fashion Carnaval di media online dalam konteks destination branding belum pernah dilakukan. Beberapa penelitian analisis isi yang pernah dilakukan antara lain sebagai berikut. Ezzy Augusta Mutiara melakukan studi analisis isi tentang kekerasan fisik dan dan psikologis dalam film "The Raid: Redemption" karya Gareth Evans (Augusta, 2013). Studi ini fokus pada analisis isi media film menggunakan pendekatan kuantitatif, yang instrumen analisis datanya menggunakan teknik analisis isi Holsti (Holsti, 1969). Hasil penelitian menunjukkan, total adegan kekerasan fisik berjumlah 1960 kali atau 85,2\%, sementara total adegan kekerasan psikologis berjumlah 323 kali atau 14,8\%. Dalam film "The Raid: Redemption" lebih mengedepankan kekerasan fisik dibandingkan kekerasan psikologis.

\section{Karakteristik Komunikasi Massa dalam Pemberitaan Jember Fashion Carnaval 2016 di Media Online}

Penyelenggaraan JFC 2016 banyak diliput dan diberitakan oleh media massa, tidak terkecuali media online. Melalui internet, informasi dapat berpindah sangat 
cepat melalui media komunikasi baru bernama media online. Dalam perspektif komunikasi massa, media online adalah media yang menyajikan karya jurnalistik berupa berita, artikel, feature secara online. Sebagai bagian dari komunikasi massa, media online dan media massa konvensional memiliki kesamaan karakteristik komunikasi massa Suprapto (2006) antara lain: 1) Sifat komunikan, yaitu komunikasi massa yang ditujukan kepada khalayak yang jumlahnya relatif besar, heterogen, dan anonim; 2) Sifat media massa, yaitu serempak dan cepat; 3 ) Sifat pesan, pesan yang disampaikan melalui media massa adalah bersifat umum (public); 3) Sifat komunikator adalah lembaga organisasi, misalnya wartawan, sutradara, penyiar, pembawa acara, adalah komunikator yang terlembagakan.

\section{Memahami Konsep Destination Branding Kota Jember}

Berbagai upaya ditempuh daerah untuk mempromosikan program pariwisatanya, salah satunya yang saat ini sedang menjadi tren adalah konsep destination branding daerah. Penyelenggaraan Jember Fashion Carnaval 2016 adalah salah satu langkah yang diambil oleh pemangku kepentingan Kota Jember dalam mewujudkan misi destination branding daerahnya sebagai kota wisata mode pertama di Indonesia dan dunia.

Hal ini sesuai dengan definisi destination branding sebagai seperangkat asosiasi merek yang dapat menjadi tanda pengenal atau pembeda suatu lokasi dengan menawarkan pengalaman berwisata yang mengesankan pada lokasi tersebut Goeldner dalam Iliachenko (2005). Morgan dan Pritchard (2004) merumuskan tahapan dalam mewujudkan destination branding daerah antara lain: 1) Market investigation, analysis and strategic recommendations. Pada tahapan ini pemangku kepentingan Kota Jember melakukan riset pemetaan potensi pasar, hal-hal apa saja yang bisa dikembangkan dan menyusun strategi. 2) Brand identity development. Brand identity dibentuk berdasarkan visi, misi, dan image yang ingin dibentuk Kota Jember, sehingga dapat dipilih tagline yang dapat merepresentasikan Kota Jember. 3) Brand launch and introduction: communicating the vision. Setelah tagline yang diusung Jember diperkenalkan, maka brand yang ada juga perlu diperkenalkan dengan melibatkan seluruh komponen yang ada melalui media relations, advertising, direct marketing, personal selling, websites, brochures, event organizers, film makers, destination marketing organizations (DMOs), serta Jurnalis. 4) Brand implementation. Brand adalah sebuah janji. Semua pihak yang terlibat mulai dari pemerintah, pihak hotel, agen travel, masyarakat Jember harus berusaha mewujudkan janji tersebut. 5) Monitoring, evaluation and review. Program destinasi Kota Jember yang sedang dilaksanakan dilakukan monitoring apakah ada penyimpangan, kekurangan dan sebagainya. Dari hasil monitoring dilakukan evaluasi dan review untuk perbaikan selanjutnya.

Elaboration Likelihood Model (ELM): Dampak Pesan Pemberitaan Jember Fashion Carnaval 2016 di Media Online Bagi Audiences

Elaboration Likelihood
digunakan dalam penelitian ini untuk menganalisis bagaimana pesan pemberitaan JFC 2016 di media online bekerja untuk memengaruhi komunikan dalam membangun persepsi atas destination branding Kota Jember. Asumsi dasar teori ini adalah terdapat dua rute kognitif untuk mengevaluasi pesan, yaitu rute sentral dan rute periferal. Proses berpikir kritis terjadi pada rute sentral, sedangkan ketiadaan proses berpikir kritis terjadi pada rute periferal. Menurut Griffin (2014), rute sentral melibatkan proses elaborasi pesan, yaitu elaborasi dimaknai sebagai sejauhmana seseorang berpikir secara seksama tentang relevansi argumen 
yang terkandung dalam suatu topik komunikasi, sedangkan rute periferal menawarkan jalan pintas untuk menerima maupun menolak pesan tanpa adanya pertimbangan terhadap objek dan atribut pesan. Terdapat enam faktor yang membuat digunakannya jalur periferal sebagai autopilot, yaitu: resiprokasi, konsistensi, bukti sosial, kesukaan, otoritas, dan kelangkaan (Littlejohn and Foss, 2009).

\section{METODE PENELITIAN}

Metode yang digunakan dalam penelitian ini adalah metode analisis isi deskriptif dengan pendekatan kuantitatif yang dapat didefinisikan sebagai suatu metode untuk mendeskripsikan hasil penelusuran informasi ke fakta yang diolah menjadi data (Kriyantono, 2007). Menganalisis pemberitaan JFC 2016 di media online yang terbit bulan Agustus September 2016. Teknik yang digunakan adalah analisis isi (content analysis) yang berfokus pada karakteristik bahasa dalam komunikasi dan isi/arti kontekstual teks (Hsieh, 2005). Objek penelitian ini adalah naskah berita JFC 2016 yang terbit di media online bulan Agustus - September 2016. Data kuantitatif yang diperoleh dianalisis dengan distribusi frekuensi dan tabulasi silang dari data-data yang terkumpul (Birowo, 2004). Adapun teknik analisis data yang digunakan adalah deskriptif dengan langkah-langkah: 1) Pengumpulan data: dilakukan dengan lembar koding (coding sheet) yang dibuat berdasarkan kategori yang ditetapkan; 2) Reduksi data: memilih data yang relevan dengan tujuan penelitian; 3) Reliabilitas menggunakan tes intercoder reliability untuk mengetahui tingkat konsistensi pengukuran. Penelitian ini menggunakan tiga koder dari latar belakang yang memahami komunikasi dan isi media.

\section{HASIL PENELITIAN DAN PEMBAHASAN}

Dari penelitian yang dilakukan, diperoleh 20 berita bertema Jember Fashion Carnaval (JFC) 2016 dari 11 media online. Setiap bagian naskah berita kemudian dianalisis mengikuti kategori unit analisis yang dijadikan acuan dalam penelitian ini mencakup: sumber informasi, konten berita, substansi destination branding, kategori berita, dan tone berita. Berikut tabel analisis isi pemberitaan Jember Fashion Carnaval (JFC) 2016 di media online.

Berdasarkan hasil uji reliabilitas yang dilakukan, persentase angka reliabilitas antarkoder berkisar antara 75 s/d 100\%. Dalam formula Holsti, angka reliabilitas minimum yang ditoleransi adalah 0,7 atau $70 \%$ (Holsti, 1969). Dengan demikian kategori unit analisis pada pemberitaan JFC 2016 di media online oleh ketiga koder adalah valid.

Tabel 1

Tabel Kategori Unit Analisis Pemberitaan Jember Fashion Carnaval 2016 di Media Online Agustus - September 2016

\begin{tabular}{|c|c|c|c|c|c|c|}
\hline No & $\begin{array}{r}\text { JUDUL } \\
\text { BERITA }\end{array}$ & $\begin{array}{l}\text { NAMA MEDIA, } \\
\text { TGL TERBIT, } \\
\text { (URL) Diakses }\end{array}$ & $\begin{array}{c}\text { RINGKASAN } \\
\text { PERNYATAAN DAN } \\
\text { SUMBER } \\
\text { INFORMASI }\end{array}$ & $\begin{array}{c}\text { SUBSTANSI } \\
\text { DESTINATION } \\
\text { BRANDING }\end{array}$ & $\begin{array}{c}\text { Kategori } \\
\text { Berita }\end{array}$ & $\begin{array}{c}\text { Tone } \\
\text { Berita }\end{array}$ \\
\hline 1 & $\begin{array}{l}\text { Diperkira } \\
\text { kan } \\
\text { Jember } \\
\text { Fashion } \\
\text { Carnaval } \\
2016 \\
\text { Akan }\end{array}$ & $\begin{array}{l}\text { harianbernas.com, } \\
26 \text { Agustus } 2016 \\
\text { (http://www.haria } \\
\text { nbernas.com/berit } \\
\text { a-20927- } \\
\text { Diperkirakan- } \\
\text { Jember-Fashion- }\end{array}$ & $\begin{array}{l}\text { Target kunjungan } \\
\text { wisatawan Tahun } 2016 \\
\text { lebih tinggi dibandingkan } \\
\text { Tahun 2015. Sekitar } \\
\text { 300.000 pengunjung itu } \\
\text { pun mulai mancanagera, }\end{array}$ & $\begin{array}{l}\text { Terdapat substansi } \\
\text { market investigation, } \\
\text { analysis and strategic } \\
\text { recommendation } \\
\text { melalui penetapan } \\
\text { target } \quad \text { wisatawan } \\
\text { sebanyak } 300.000\end{array}$ & Event & Positif \\
\hline
\end{tabular}




\begin{tabular}{|c|c|c|c|c|c|c|}
\hline & $\begin{array}{l}\text { Menarik } \\
\text { Ratusan } \\
\text { Ribu } \\
\text { Wisataw } \\
\text { an }\end{array}$ & $\begin{array}{l}\text { Carnaval-2016- } \\
\text { Akan-Menarik- } \\
\text { Ratusan-Ribu- } \\
\text { Wisatawan-.html) } \\
\text { diakses } 11 \\
\text { September } 2016\end{array}$ & $\begin{array}{l}\text { domestik, juga termasuk } \\
\text { anak anak. Sumber: } \\
\text { Plt. Kepala Kantor } \\
\text { Pariwisata } \\
\text { Kebudayaan } \\
\text { Jember } \quad \text { Kabupaten } \\
\text { Satuki. }\end{array}$ & $\begin{array}{lr}\text { orang. } & \text { Terdapat } \\
\text { substansi } & \text { brand } \\
\text { identity development } \\
\text { "world class street } \\
\text { fashion carnaval". }\end{array}$ & & \\
\hline 2 & $\begin{array}{l}\text { Bupati } \\
\text { Bangga } \\
\text { dengan } \\
\text { Jember } \\
\text { Fashion } \\
\text { Carnaval }\end{array}$ & $\begin{array}{l}\text { Viva.co.id, } 28 \\
\text { Agustus } 2016 \\
\text { (http://life.viva.co } \\
\text { id/news/read/814 } \\
\text { 567-bupati- } \\
\text { bangga-dengan- } \\
\text { jember-fashion- } \\
\text { carnaval) diakses } \\
4 \text { September } 2016\end{array}$ & $\begin{array}{l}\text { JFC adalah kebanggan } \\
\text { bagi Kota Jember. } \\
\text { Membuat nama Jember } \\
\text { dikenal dunia. Sumber: } \\
\text { Bupati Jember, dr. Hj. } \\
\text { Faida. }\end{array}$ & $\begin{array}{l}\text { Terdapat substansi } \\
\text { brand identity } \\
\text { development } \\
\text { mengenai deskripsi } \\
\text { image Kota Jember. }\end{array}$ & News & Positif \\
\hline 3 & $\begin{array}{l}\text { Cerita di } \\
\text { Balik } \\
\text { Terbentu } \\
\text { knya } \\
\text { Jember } \\
\text { Fashion } \\
\text { Carnaval } \\
2016\end{array}$ & $\begin{array}{l}\text { Viva.co.id, } 27 \\
\text { Agustus } 2016 \\
\text { (http://life.viva.co } \\
\text { id/news/read/814 } \\
\text { 319-cerita-di- } \\
\text { balik- } \\
\text { terbentuknya- } \\
\text { jember-fashion- } \\
\text { carnaval-2016) } \\
\text { diakses } \\
\text { September 2016 }\end{array}$ & $\begin{array}{l}\text { Dimulai dari komunitas } \\
\text { keluarga kami ada yang } \\
11 \text { bersaudara punya ide } \\
\text { untuk bikin acara yang } \\
\text { tidak membosankan dan } \\
\text { semenjak itu tertarik } \\
\text { mendirikan JFC Tahun } \\
\text { 2002-2003. Sumber: } \\
\text { Presiden dan penggagas } \\
\text { JFC, Dynand Fariz. }\end{array}$ & $\begin{array}{l}\text { Terdapat substansi } \\
\text { brand launch and } \\
\text { introduction: dengan } \\
\text { memanfaatkan } \\
\text { jurnalis untuk } \\
\text { menceritakan kisah di } \\
\text { balik lahirnya } \\
\text { gagasan JFC. }\end{array}$ & News & Netral \\
\hline 4 & $\begin{array}{l}\text { Anang: } \\
\text { Jember } \\
\text { Fashion } \\
\text { Carnaval } \\
\text { Belum } \\
\text { Untungk } \\
\text { an } \\
\text { Masyara } \\
\text { kat }\end{array}$ & $\begin{array}{l}\text { tribunnews.com, } \\
29 \text { Agustus } 2016 \\
\text { (http://www.tribu } \\
\text { nnews.com/tribun } \\
\text { ners/2016/08/29/a } \\
\text { nang-jember- } \\
\text { fashion-carnival- } \\
\text { belum-untungkan- } \\
\text { masyarakat?page } \\
=2 \text { ) diakses } 4 \\
\text { September } 2016\end{array}$ & $\begin{array}{l}\text { 1. Semestinya gelaran } \\
\text { JFC yang luar biasa ini } \\
\text { dapat disinergikan } \\
\text { dengan berbagai sektor. } \\
\text { 2. Saya angkat topi atas } \\
\text { dedikasi Dynan Fariz dan } \\
\text { tim penyelenggara JFC } \\
\text { yang mengangkat Jember } \\
\text { di pentas dunia. } \\
\text { 3. Jangan sampai JFC } \\
\text { yang megah ini hadir di } \\
\text { tengah-tengah } \\
\text { kemiskinan masyarakat } \\
\text { Jember. } \\
\text { 4. Saya membayangkan, } \\
\text { makanan dan buah- } \\
\text { buahan yang disajikan di } \\
\text { JFC adalah seluruhnya } \\
\text { produk lokal Jember. } \\
\text { 5. Janji Jember Baru oleh } \\
\text { kepala daerah baru belum } \\
\text { tampak dalam } \\
\text { pengelolaan JFC ini. } \\
\text { Sumber: Anggota Komisi } \\
\text { X DPR RI, Anang } \\
\text { Hermansyah. }\end{array}$ & $\begin{array}{l}\text { Terdapat substansi } \\
\text { market investigation, } \\
\text { analysis and strategic } \\
\text { recommendations: } \\
\text { rekomendasi Anang } \\
\text { Hermansyah terhadap } \\
\text { penyelenggaraan JFC } \\
\text { yang seharusnya } \\
\text { melibatkan seluruh } \\
\text { potensi dan } \\
\text { masyarakat Jember. } \\
\text { Terdapat substansi } \\
\text { monitoring, } \\
\text { evaluation and review } \\
\text { terhadap Pemda dan } \\
\text { Kepala Daerah } \\
\text { Jember untuk bisa } \\
\text { merajut seluruh } \\
\text { potensi Jember. }\end{array}$ & Budaya & Negatif \\
\hline 5 & $\begin{array}{l}\text { Peserta } \\
\text { Jember } \\
\text { Fashion }\end{array}$ & $\begin{array}{l}\text { tribunnews.com, } 1 \\
\text { September } 2016\end{array}$ & $\begin{array}{lrr}\text { Berat } & \text { sih, tapi } & \text { mampu } \\
\text { bawa } & \text { sampai } & \text { finis. }\end{array}$ & $\begin{array}{l}\text { Terdapat substansi } \\
\text { brand } \\
\text { implementation: }\end{array}$ & News & Netral \\
\hline
\end{tabular}


Carnaval (http://www.tribu

Pakai nnews.com/video/

Kostum 2016/09/01/pesert

Seberat a-jember-fashion-

$15-40 \mathrm{Kg}$ carnafal-pakai-

kostum-seberat-

$15-40-\mathrm{kg})$ diakses

4 September 2016

$6 \quad 10$ Defile suryamalang.tribu

Meriahka nnews.com, 28

n Puncak Agustus 2016

Jember (http://suryamalan

Fashion g.tribunnews.com

Carnaval /2016/08/28/10-

Hari Ini defile-meriahkan-

puncak-jember-

fashion-carnaval-

hari-ini) diakses 9

September 2016

7 Asian

Games

2018

Dipromo

sikan di

Ajang

JFC 2016

republika.co.id, 28 Agustus 2016

(http://www.repub

lika.co.id/berita/ol

ahraga/arena-

olahraga/16/08/28

/ocmo8f372-

asian-games-

2018-

dipromosikan-di-

ajang-jfc-2016)

diakses

11

September 2016

8 JFC

okezone.com, 29

2016, Ini Agustus 2016

Mimpi (http://lifestyle.ok

Dynand

Fariz

yang

Belum

Terwujud 75903/jfc-2016 ini-mimpidynand-fariz-
Sumber: Peserta Defile

Oceans, Shinta.

10 defile yang diangkat mengggambarkan

kebangkitan Indonesia

dalam berbagai bidang.

Sumber: Presiden JFC

Dynand Fariz.

1. Partisipasi INASGOC

di arena ini untuk

mempromosikan Asian

Games 2018.

2. JFC tarafnya sudah go internasional dan tepat jika Asian Games 2018 turut dipertontonkan di ajang itu. Sumber: Sekjen INASGOC, Sylviana Murni.

Aku ingin Indonesia terus berkibar di seluruh dunia. $\mathrm{Aku}$ ingin JFC bisa disaksikan secara live oleh penonton dunia. Sumber: Presiden JFC Dynand Fariz. yang-belumterwujud) diakses 10 September 2016

9 Menteri

Susi

Pudjiastu

ti Nongol

di Acara

Puncak

Jember

Fashion

Carnaval

2016 okezone.com, 29 Agustus 2016

(http://lifestyle.ok ezone.com $/ \mathrm{read} / 2$ 016/08/28/194/14 75151/menterisusi-pudjiastutinongol-di-acarapuncak-jemberfashion-carnaval-
1. Saya bangga karena JFC kali ini banyak mengangkat budaya lokal dan nasional.

2. Jember Fashion Carnaval ke-15 semakin lengkap dengan kehadiran para peserta yang berkebutuhan khusus dan kaum dhuafa, partisipasi warga

Jember seperti yang dilakukan oleh Shinta dalam JFC 2016.

Terdapat substansi News Positif brand identity development: JFC

2016

merepresentasikan

kebangkitan

Indonesia melalui tagline "Revival" Indonesia to The World.

Terdapat substansi Olah

Positif brand launch and Raga introduction:

Mengenalkan

program INASGOC berupa promosi Asian Games di ajang internasional Jember Fashion Carnaval (JFC) 2016.

Terdapat substansi market investigation, analysis and strategic recommendations:

Dynand Fariz

menginginkan JFC tayang secara live. Terdapat substansi brand implementation:

Dynan Fariz menginginkan

Indonesia terkenal melalui JFC.

Terdapat substansi Lifestyle Positif brand

implementation: JFC 2016 melibatkan peserta yang berkebutuhan khusus dan kaum dhuafa, serta anak-anak yang telah menjalani

Lifestyle Positif

\section{C}

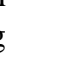




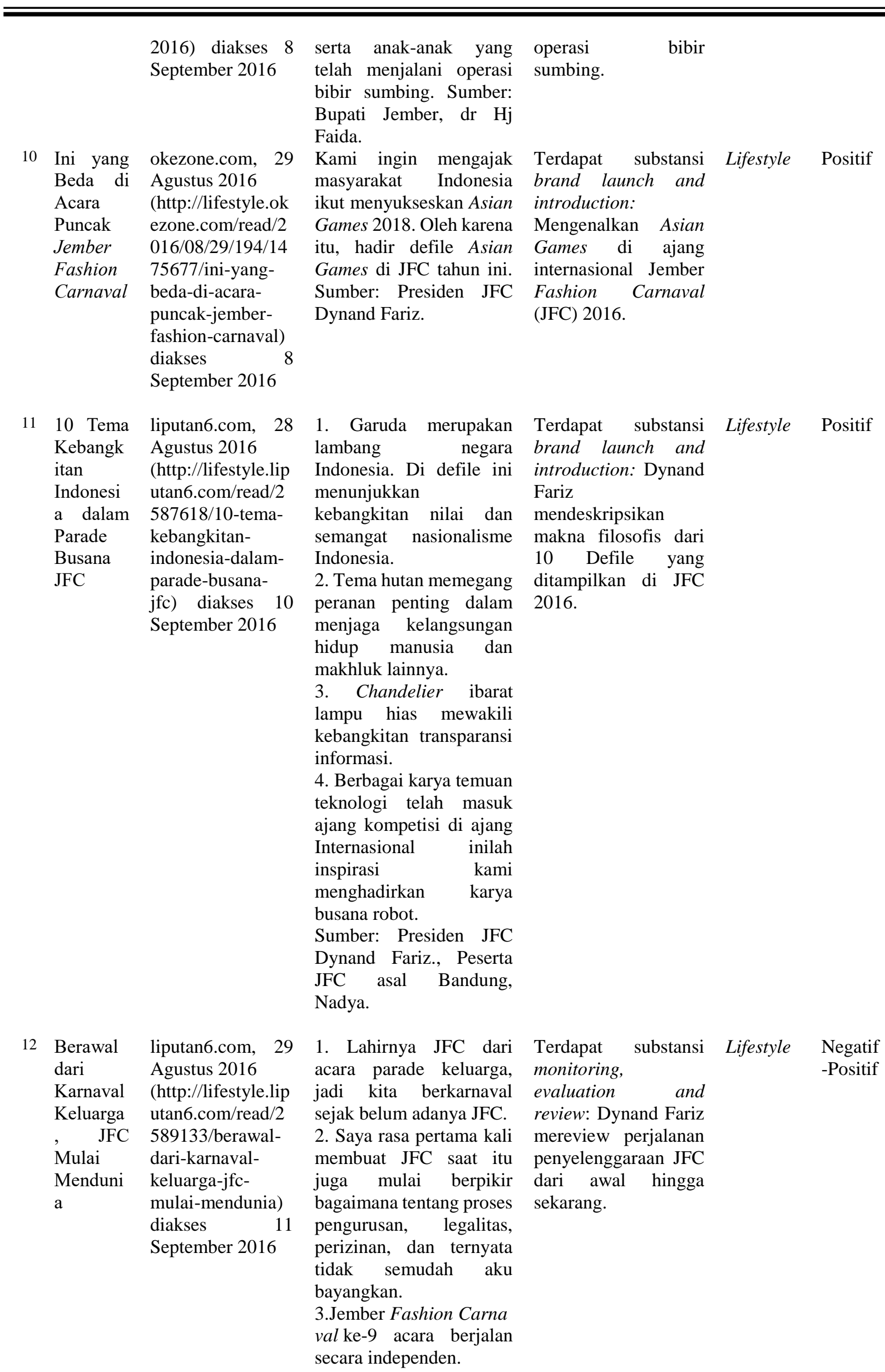


4. Aku juga ingin mengenalkan JFC kepada para pengunjung di mal, namun sekuriti justru mengusir kami.

5. Keinginan aku cuma satu dan itu mimpi yang belum terwujud, yaitu secara live.

Sumber: Founder JFC, Dynand Fariz.

13 Jember liputan6.com, 29 1. Kalau kita bicara Fashion Agustus 2016

Carnaval (http://lifestyle.lip

Duduki utan6.com/read/2

Peringkat 589138/jember-

4 fashion-carnaval-

Karnaval duduki-peringkat-

Dunia

4-karnaval-dunia)

diakses

11

September 2016

dukungan disini tentunya

yang aku lihat dari

dukungan yang positif,

dan saya rasa itu kembali

pada masyarakat yang

menilai dan merasakan.

2. Saya juga tentunya

sebagai penyelenggara

akan terus mengevaluasi apakah saya juga sudah maksimal apa yang saya lakukan dan berikan kepada masyarakat.

3. Tahun ini tidak sama rapi dengan tahun sebelumnya. Maka itu, perlu ada evaluasi yang menyeluruh.

Sumber: Founder JFC, Dynand Fariz.

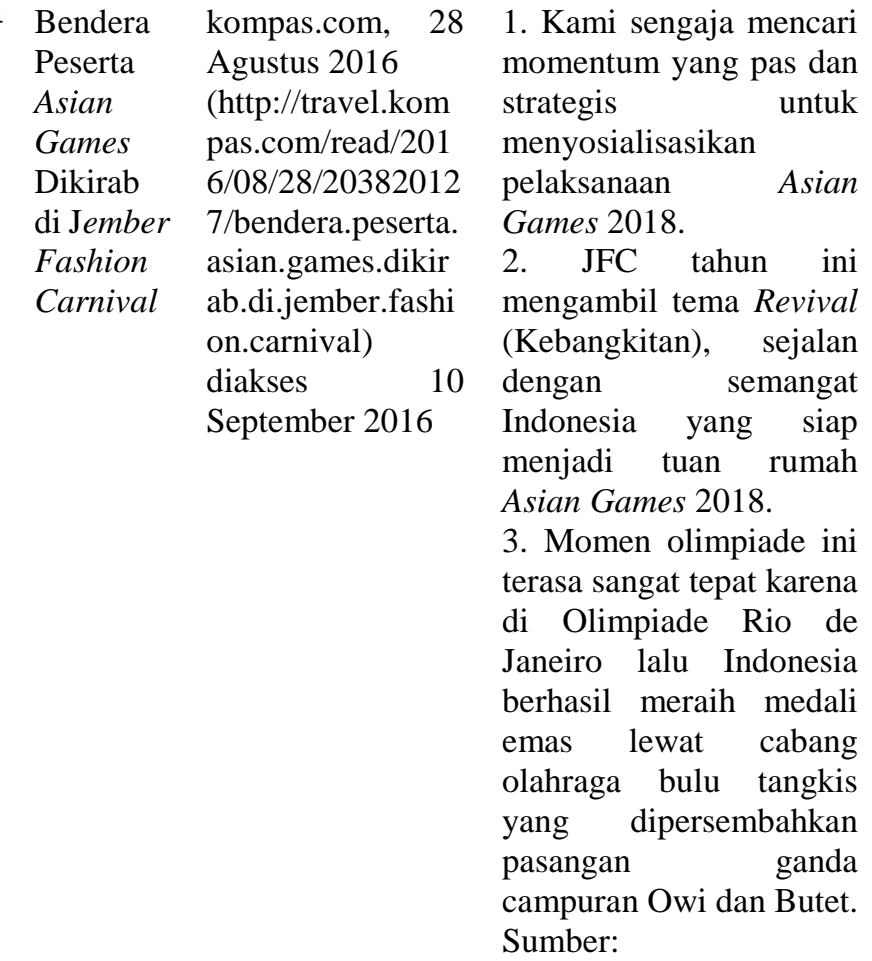

Terdapat substansi Lifestyle Positifmonitoring, Negatif evaluation and review: Dynand Fariz mereview dan mengevaluasi penyelenggaraan JFC 2016.

Terdapat substansi

Travel

Positif brand launch and introduction:

Mengenalkan Asian Games di ajang internasional Jember Fashion Carnaval (JFC) 2016. 


\begin{tabular}{|c|c|c|c|c|c|c|}
\hline & & & $\begin{array}{l}\text { Sekretaris } \quad \text { Jenderal } \\
\text { INASGOC, } \quad \text { Sylviana } \\
\text { Murni. Warga, Ahmad. }\end{array}$ & & & \\
\hline 15 & $\begin{array}{l}\text { Ini Dia } \\
\text { Kostum } \\
\text { Terberat } \\
\text { di } \\
\text { Jember } \\
\text { Fashion } \\
\text { Carnaval } \\
2016\end{array}$ & $\begin{array}{l}\text { kompas.com, } 30 \\
\text { Agustus } 2016 \\
\text { (http://female.ko } \\
\text { mpas.com/read/20 } \\
\text { 16/08/30/0931002 } \\
\text { 20/Ini.Dia.Kostu } \\
\text { m.Terberat.di.Jem } \\
\text { ber.Fashion.Carna } \\
\text { val.2016) diakses } \\
8 \text { September } 2016\end{array}$ & $\begin{array}{l}\text { Kostum yang terberat } \\
\text { mencapai } 40 \text { kilogram. } \\
\text { Kostum yang terberat } \\
\text { adalah kostum barong } \\
\text { merupakan simbol yang } \\
\text { dapat menyemangati } \\
\text { kebangkitan seni budaya } \\
\text { Indonesia. } \\
\text { Sumber: Founder JFC, } \\
\text { Dynand Fariz. }\end{array}$ & $\begin{array}{l}\text { Terdapat substansi } \\
\text { brand launch and } \\
\text { introduction: Dynand } \\
\text { Fariz } \\
\text { mendeskripsikan } \\
\text { makna filosofis defile } \\
\text { Barong Bali yang } \\
\text { ditampilkan di JFC } \\
\text { 2016. }\end{array}$ & $\begin{array}{l}\text { Fashion/ } \\
\text { Female }\end{array}$ & Positif \\
\hline 16 & $\begin{array}{l}\text { Ada } \\
\text { Shuttle } \\
\text { Cock di } \\
\text { Jember } \\
\text { Fashion } \\
\text { Carnaval }\end{array}$ & $\begin{array}{l}\text { Beritajatim.com, } \\
28 \text { Agustus } 2016 \\
\text { (http://beritajatim. } \\
\text { com/gaya_hidup/ } \\
\text { 275227/ada_shuttl } \\
\text { e_cock_di_jember } \\
\text { fashion_carnaval } \\
\text {.html) diakses } 9 \\
\text { September } 2016\end{array}$ & $\begin{array}{l}\text { 1. Kami pilih kostum } \\
\text { berornamen bulutangkis, } \\
\text { panahan, dan anggar. Ada } \\
\text { juga Wall of Fame, } \\
\text { Energy of Asia. } \\
\text { 2. Kami akan terus } \\
\text { terlibat di berbagai } \\
\text { kegiatan skala nasional } \\
\text { dan internasional seperti } \\
\text { ini untuk empromosikan } \\
\text { Asian Games. } \\
\text { Sumber: Sekretaris } \\
\text { Jenderal INASGOC, } \\
\text { Sylviana Murni. }\end{array}$ & $\begin{array}{l}\text { Terdapat substansi } \\
\text { brand launch and } \\
\text { introduction: } \\
\text { Mengenalkan Asian } \\
\text { Games di ajang } \\
\text { internasional Jember } \\
\text { Fashion Carnaval } \\
\text { (JFC) 2016. }\end{array}$ & Lifestyle & Positif \\
\hline 17 & $\begin{array}{l}\text { Hujan } \\
\text { Hancurk } \\
\text { an } \\
\text { Keindaha } \\
\text { n Jember } \\
\text { Fashion } \\
\text { Carnaval }\end{array}$ & $\begin{array}{l}\text { Beritajatim.com, } \\
28 \text { Agustus } 2016 \\
\text { (http://beritajatim. } \\
\text { com/gaya_hidup/ } \\
\text { 275207/hujan_ha } \\
\text { ncurkan_keindaha } \\
\text { n_jember_fashion } \\
\text { _carnaval.html) } \\
\text { diakses } \\
\text { September 2016 }\end{array}$ & $\begin{array}{l}\text { 1. Secara umum ada yang } \\
\text { berbeda dalam JFC kali } \\
\text { ini. Kurang greget } \\
\text { dibandingkan tahun lalu. } \\
\text { 2. Penampilan defile di } \\
\text { depan tamu VIP } \\
\text { terlampau lama. } \\
\text { 3. Seharusnya lebih } \\
\text { bagus. Tapi saya lihat } \\
\text { display-nya kurang oke. } \\
\text { Sumber: Pimpinan } \\
\text { Kantor Bank Indonesia } \\
\text { Jember Achmad } \\
\text { Bunyamin. }\end{array}$ & $\begin{array}{lr}\text { Terdapat substansi } \\
\text { monitoring, } \\
\text { evaluation } r \text { and } \\
\text { review: } \quad \text { Warga } \\
\text { masyarakat mereview } \\
\text { dan mengevaluasi } \\
\text { penyelenggaraan JFC } \\
2016 \text {. }\end{array}$ & Lifestyle & Negatif \\
\hline 18 & $\begin{array}{l}\text { Jangan } \\
\text { Lewatka } \\
\mathrm{n}, \\
\text { Penampil } \\
\text { an } \\
\text { Malam } \\
\text { Hari } \\
\text { Jember } \\
\text { Fashion } \\
\text { Carnaval }\end{array}$ & $\begin{array}{l}\text { detik.com, } 31 \\
\text { Agustus } 2016 \\
\text { (http://travel.detik } \\
. c o m / \text { read/2015/0 } \\
\text { 8/31/180405/3006 } \\
\text { 183/1382/jangan- } \\
\text { lewatkan- } \\
\text { penampilan- } \\
\text { malam-hari- } \\
\text { jember-fashion- } \\
\text { carnaval) diakses } \\
11 \quad \text { September } \\
2016 \quad\end{array}$ & $\begin{array}{l}\text { 1. Kemarin kan JFC } \\
\text { tampil siang hari di alun- } \\
\text { alun Kota Jember. Nah } 2 \\
\text { September mendatang } \\
\text { JFC hadir perdana di } \\
\text { Stadion Jember. } \\
\text { 2. Karena penampilannya } \\
\text { malam hari, nanti akan } \\
\text { ada pertunjukan lampu } \\
\text { dan lain-lain. } \\
\text { Sumber: Kepala Dinas } \\
\text { Kebudayaan dan } \\
\text { Pariwisata Kabupaten } \\
\text { Jember, Sandi Suwardi } \\
\text { Hasan. }\end{array}$ & $\begin{array}{l}\text { Terdapat substansi } \\
\text { brand launch and } \\
\text { introduction: Kepala } \\
\text { Dinas Kebudayaan } \\
\text { dan Pariwisata } \\
\text { Kabupaten Jember } \\
\text { mengenalkan konsep } \\
\text { penampilan JFC 2016 } \\
\text { pada malam hari. }\end{array}$ & Travel & Positif \\
\hline
\end{tabular}


19 JFC Antaranews.com, mempeso 28 Agustus 2016 na bagi (http://www.antar jurnalis
20

$\begin{array}{ll}\text { Peserta } & \text { Antaranews.com, } \\ \text { Jember } & \text { 24 Agustus 2016 } \\ \text { Fashion } & \text { (http://www.antar } \\ \text { Carnival } & \text { anews.com/berita/ } \\ \text { habiskan } & \text { 580537/peserta- } \\ \text { jutaan } & \text { jember-fashion- } \\ \text { rupiah } & \text { carnival- } \\ \text { untuk } & \text { habiskan-jutaan- } \\ \text { kostum } & \text { rupiah-untuk- } \\ & \text { kostum) diakses } \\ & 10 \quad \text { September } \\ & 2016\end{array}$

1. Kegiatan JFC sangat luar biasa, sehingga saya ingin membuat film dokumenter tentang karnaval yang sudah mendunia ini.

2. Kami kagum dengan ide-idenya yang luar biasa dan busana yang digunakan peserta juga bagus. campaign $=$ news diakses 10

September 2016

\section{Sumber:}

Terdapa monitoring evaluation substansi News

Positif review: Jurnalis dan wisatawan asing mengungkapkan

kesannya yang merupakan review terhadap pelaksanaan JFC 2016.

Jurnalis Swiss TV, Edy F.

Wales.

Wisatawan perempuan asal Perancis Clo Meunier.

1.Total pengeluaran untuk membeli bahanbahan pembuatan kostum defile Garuda berkisar Rp. 2 juta lebih.

2. Nama JFC sudah mendunia dan dikenal oleh masyarakat internasional, sehingga saya bangga bisa menjadi bagian dari kegiatan.

Sumber: Peserta JFC, Imron, Rika.
Terdapat substansi News Positif brand

implementation: yaitu melibatkan partisipasi masyarakat untuk turut serta dalam pelaksanaan JFC 2016.

Sumber: Media Online, data diolah peneliti.

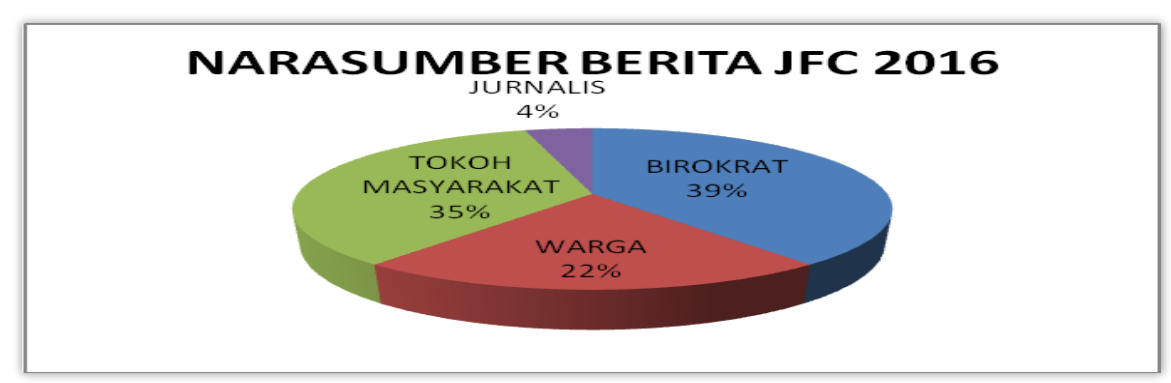

Sumber: Hasil Penelitian, Data Diolah Peneliti

Gambar 1. Persentase Narasumber Berita JFC 2016

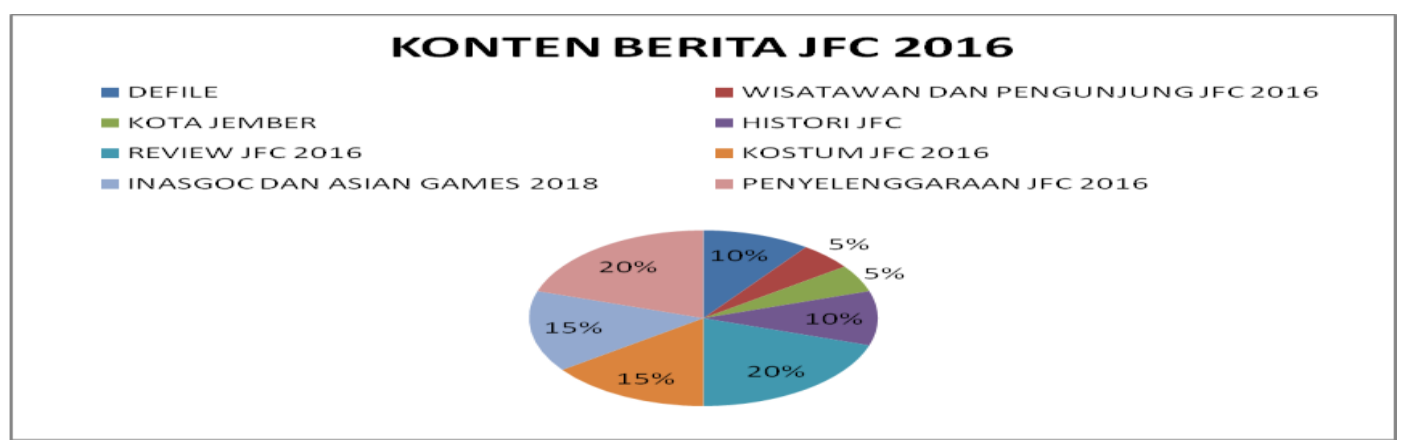

Sumber: Hasil Penelitian, Data Diolah Peneliti.

Gambar 2. Persentase Konten Berita JFC 2016 


\section{Kategori Sumber Informasi}

Pemberitaan JFC 2016 di media online menurut kategori sumber informasinya dapat dilihat pada Gambar 1 Dari data tersebut terlihat bahwa klasifikasi narasumber berita JFC 2016 terbagi ke dalam empat golongan yaitu: Tokoh Masyarakat (Presiden dan Penggagas JFC, Dynand Fariz), Warga (Peserta Defile Oceans, Shinta; Peserta JFC asal Bandung, Nadya; Warga, Ahmad; Wisatawan perempuan asal Perancis, Clo Meunier; Peserta JFC, Imron dan Rika), Birokrat (Plt. Kepala Kantor Pariwisata dan Kebudayaan Kabupaten Jember Muhammad Satuki, Bupati Jember dr. Hj. Faida, Anggota Komisi X DPR RI Anang Hermansyah, Sekjen INASGOC Sylviana Murni, Pimpinan Kantor Bank Indonesia Jember Achmad Bunyamin, Kepala Dinas Kebudayaan dan Pariwisata Kabupaten Jember Sandi Suwardi Hasan), dan Jurnalis (Jurnalis Swiss TV, Edy F. Wales).

\section{Kategori Konten Berita}

$\begin{array}{crr}\text { Konten } & \text { berita JFC } & 2016 \\ \text { diklasifikasikan } & \text { berdasarkan } & \text { topik }\end{array}$ pemberitaan yang muncul di media online periode Agustus - September 2016 antara lain terbagi menjadi delapan kategori: Defile, Wisatawan/pengunjung JFC 2016, Kota Jember, Histori JFC, Review JFC 2016, Kostum JFC 2016, INASGOC dan Asian Games 2018 di JFC 2016, serta Penyelenggaraan JFC 2016. Persentase keberagaman konten berita JFC 2016 dapat dilihat pada diagram Gambar 2. Konten berita JFC 2016 di media online diperoleh dari pernyataan narasumber berita. Berita JFC 2016 paling banyak memuat konten mengenai review JFC 2016 dan Penyelenggaraan JFC 2016 masing-masing sebanyak empat topik (20\%).

\section{Kategori Substansi Destination Branding}

Core analisis dalam penelitian ini adalah mendeskripsikan analisis isi berita JFC 2016 yang berkaitan dengan destination branding Kota Jember sebagai pengetahuan kontekstual agar penelitian tidak berada di ruang hampa. Morgan dan Pritchard merumuskan lima tahapan dalam mewujudkan destination branding daerah yang menjadi panduan analisis kategori substansi destination branding dalam pemberitaan JFC 2016 (Morgan et al., 2004). Dari semua berita JFC 2016 yang dianalisis pada penelitian ini memuat substansi destination branding dalam pesan yang disampaikan dengan kategori yang berbeda-beda menurut lima tahapan destination branding. Persentase terbanyak adalah berita yang memuat konten Brand launch and introduction: communicating the vision yaitu sebesar 35\% (delapan pernyataan narasumber) yang mengulas pesan terkait: partisipasi warga Jember dari berbagai kalangan dalam JFC 2016, keterlibatan Jurnalis dalam pemberitaan JFC 2016, promosi kolaboratif antara INASGOC dan JFC 2016, makna filosofis 10 Defile yang ditampilkan dalam JFC 2016.

Konten Brand launch and introduction: communicating the vision tersebut berkaitan dengan proses mengomunikasikan visi, misi, dan ide JFC 2016 dengan melibatkan publik. Tahapan Market investigation, analysis and strategic recommendations memiliki persentase $13 \%$ yang umumnya berisi pemberitaan mengenai target kunjungan wisatawan pada JFC 2016, rekomendasi penyelenggaraan JFC 2016, dan perencanaan JFC mendatang. Tahapan Brand identity development memiliki porsi $13 \%$ terdiri dari berita pembangunan image "World Class Street Fashion Carnaval", deskripsi citra Kota Jember, dan penggambaran image JFC 2016 yang merepresentasikan kebangkitan Indonesia melalui tagline "Revival" Indonesia to The World.

Konten berita yang berisi brand implementation adalah sebesar $17 \%$ terdiri dari berita mengenai partisipasi warga Jember di JFC 2016 dari berbagai lapisan termasuk kaum dhuafa dan anak-anak yang telah menjalani operasi bibir sumbing. 
Tahapan terakhir dalam pengembangan destination branding adalah monitoring, evaluation and review. Berita JFC 2016 yang mengulas monitoring, evaluation and review memiliki persentase sebesar $22 \%$ yaitu merepresentasikan pendapat narasumber dalam memonitor dan mengevaluasi penyelenggaraan JFC 2016 (Gambar 3).

\section{Kategori Berita}

Klasifikasi kategori berita dalam penelitian analisis isi pemberitaan JFC 2016 terdiri dari tujuh tema antara lain: Event, News, Budaya, Olah Raga, Lifestyle, Travel, dan Fashion and Female. Klasifikasi kategori berita JFC 2016 tersebut diperoleh berdasarkan penggolongan tema berita di masingmasing media online. Persentase terbanyak atas penggolongan berita JFC 2016 adalah berita dengan kategori Lifestyle (40\%). Penggolongan berita JFC 2016 sebagai Lifestyle ini dapat ditemukan pada media okezone.com, liputan6.com, dan beritajatim.com. Sedangkan $30 \%$ berita JFC 2016 masuk dalam kategori News berupa "Soft News" yaitu berita ringan yang bersifat menghibur atau laporan event JFC 2016 yang bersifat humanis.

\section{Kategori Tone Pemberitaan}

Tone pemberitaan positif berisi pesan mengenai peningkatan jumlah wisatawan yang mengunjungi JFC 2016, kebanggaan Jember atas penyelenggaraan JFC 2016, 10 defile yang menggambarkan kebangkitan Indonesia, promosi Asian Games 2018 di JFC 2016, komentar wisatawan asing terhadap JFC 2016. Tone berita positif mengenai JFC 2016 dapat ditemukan pada media harianbernas.com, Viva.co.id, suryamalang.tribunnews.com,republika.co. id, okezone.com, liputan6.com, kompas.com, Beritajatim.com, detik.com, dan Antaranews.com. Penggunaan kata
"Wisatawan Tahun 2016 lebih tinggi dibandingkan Tahun 2015" dan "JFC adalah kebanggaan bagi Kota Jember" oleh narasumber merepresentasikan sudut pandang positif khususnya bagi kepentingan JFC itu sendiri. Selain itu, tone berita negatif pada pemberitaan JFC 2016 memiliki persentase $18 \%$ dari total pemberitaan yang dianalisis. Tone berita negatif ini berhubungan dengan isi pesan mengenai evaluasi narasumber terhadap penyelenggaraan JFC 2016.

Heath (2005) mengklasifikasikan tone artikel berita pada analisis isi media mencakup positif, negatif, dan netral. Tone berita positif paling banyak muncul dalam pemberitaan JFC 2016 (73\%), negatif 18\%, netral 9\%, dan sensitif tidak ada.

\section{Pemberitaan Jember Fashion Carnaval 2016 di Media online: Sebuah Komunikasi Massa dan Implikasinya pada Destination Branding Kota Jember}

Pesan yang dikomunikasikan melalui pemberitaan JFC 2016 di media sosial adalah bentuk komunikasi massa, sesuai dengan karakteristik komunikasi massa antara lain: 1) Pernyataan narasumber yang mengarah pada review dan penyelenggaraan JFC 2016 lebih sering muncul sebagai pesan yang bersifat umum sesuai dengan karakteristik komunikasi massa (Suprapto, 2006) yang mendeskripsikan kesan, pandangan, dan komentar narasumber atas event JFC 2016; 2) Klasifikasi narasumber terbanyak dari kalangan birokrat, hal ini mengacu ada profesi orang yang bekerja secara formal pada lembaga Negara/Pemerintahan. Kalangan birokrat mendominasi sebagai narasumber dalam pemberitaan JFC 2016 karena penyelenggaraan JFC 2016 melibatkan Pemerintah Daerah Jember dan pejabat sebagai tamu undangan seperti: Anggota Komisi X DPR RI, Anang Hermansyah dan Menteri Kelautan dan Perikanan RI, Susi Pudjiastuti. 


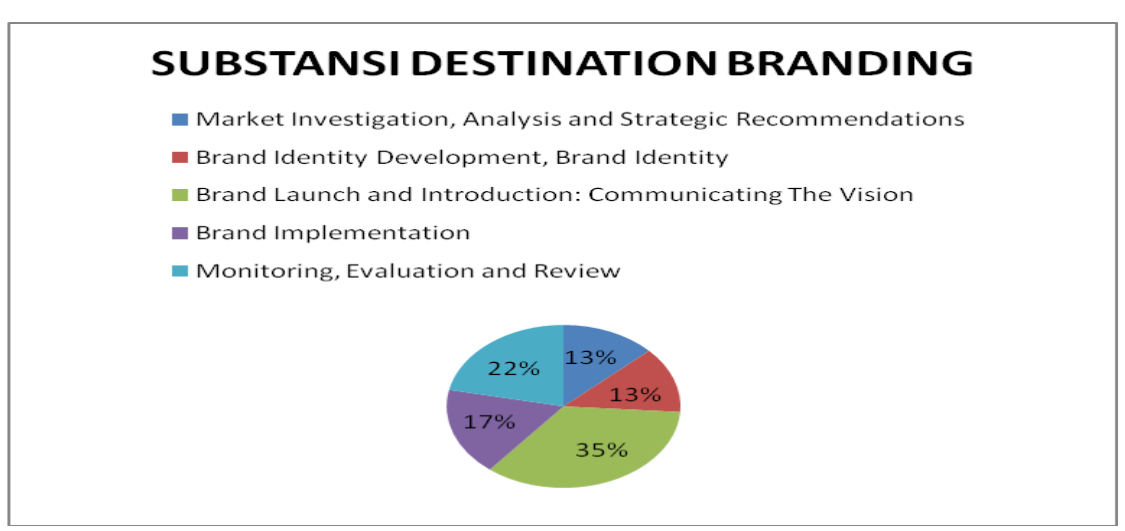

Sumber: Hasil Penelitian, Data Diolah Peneliti.

Gambar 3. Persentase Substansi Destination Branding

Pemberitaan JFC 2016 di media online berimplikasi pada implementasi destination branding Kota Jember berdasarkan lima tahapan pengembangan destination branding Morgan dan Pritchard (Morgan et al., 2004): 1) Market Investigation, Analysis and Strategic Recommendations: Pemberitaan JFC 2016 pada tahapan ini merepresentasikan ulasan narasumber atas penyelenggaraan JFC 2016 dan perencanaan JFC mendatang. Hal ini bermanfaat bagi pemangku kepentingan Kota Jember dalam menyusun strategi destination branding yang lebih baik; 2) Brand Identity Development. Brand Identity: Pemberitaan JFC 2016 terbanyak mengandung konten tahapan ini yaitu merepresentasikan kontribusi pemberitaan media yang menginformasikan pesan filosofis 10 defile yang ditampilkan dalam JFC 2016 menandakan bahwa visi misi JFC 2016 terkomunikasikan dengan baik kepada publik; 3) Brand Launch and Introduction: Pemberitaan JFC 2016 pada tahap ini merepresentasikan pembangunan image JFC 2016 dan asosiasi Kota Jember sebagai "World Class Street Fashion Carnaval" melalui tagline "Revival" Indonesia to The World pada JFC 2016; 4) Brand Implementation: Partisipasi warga Jember di JFC 2016 dari berbagai lapisan termasuk kaum dhuafa dan anak-anak yang telah menjalani operasi bibir sumbing banyak diangkat dalam pemberitaan JFC 2016. Pihak-pihak yang terlibat mulai dari pemerintah, pihak hotel, agen travel, masyarakat Jember dalam JFC 2016 adalah representasi komitmen dan partisipasi berbagai pihak dalam mendukung penyelenggaraan JFC 2016. 5) Monitoring, Evaluation and Review: Pemberitaan JFC 2016 ada tahap ini merepresentasikan pendapat narasumber dalam memonitor dan mengevaluasi penyelenggaraan JFC 2016. Umumnya berisi tentang review, kesan, dan evaluasi narasumber berita mengenai pelaksanaan JFC 2016.

\section{PENUTUP}

\section{Simpulan}

Pemberitaan Jember Fashion Carnaval (JFC) 2016 dianalisis berdasarkan kategori unit analisis: sumber informasi, konten berita, substansi destination branding, kategori berita, dan tone berita. Diperoleh hasil analisis frekuensi sumber informasi terbanyak dari birokrat (39\%), konten berita terbesar berisi topik review JFC 2016 dan penyelenggaraan JFC 2016 masing-masing sebanyak (20\%), kategori berita terbanyak bertema lifestyle (40\%), dan didominasi tone berita positif $(70 \%)$.

Pemberitaan Jember Fashion Carnaval (JFC) 2016 memuat informasi 5 tahapan destination branding mulai dari tahap Market investigation, analysis and strategic recommendations; Brand identity development; Brand launch and introduction: communicating the vision; 
Brand implementation; hingga Monitoring, evaluation and review. Masing-masing berita bisa mengandung satu atau dua unsur tahapan destination branding Kota Jember. Karena penyelenggaraan JFC 2016 adalah bagian dari upaya destination branding Kota Jember.

Hasil analisis isi berita JFC 2016 menunjukkan bahwa penyelenggara JFC 2016 telah mengomunikasikan destination branding Kota Jember dengan baik. Hasil penelitian ini dapat dijadikan panduan bagi penyelenggara JFC dalam menyusun perencanaan yang lebih baik pada event mendatang dan memberi peta evaluasi penyelenggaraan JFC 2016.

\section{Saran}

Lebih jauh penelitian ini dapat dikembangkan dengan memperdalam fokus penelitian berupa dampak pemberitaan JFC 206 terhadap komunikan yang dapat dilakukan mengikuti Elaboration Likelihood Model atau menggunakan pendekatan penelitian lainnya yang mendukung tujuan penelitian.

\section{DAFTAR PUSTAKA}

Augusta, E. (2013). TAMPILAN KEKERASAN DALAM FILM (Studi Analisis Isi Tentang Kekerasan Fisik dan Psikologis Dalam Film'The Raid: Redemption' Karya Gareth Evans). FLOW, 2 (5). [Online]. Available at: http://jurnal.usu.ac.id/index.php/flow/art icle/view/11348.

Birowo, M. A. (2004). Metode Penelitian Komunikasi, Teori dan Aplikasi. Yogyakarta: Gitanyali.

Griffin, E. A. (2014). A First Look at Communications Theory. 9th ed. New York: Mc Graw-Hill.
Heath, R. L. (2005). Encyclopedia of Public Relations. Volume 1. California: Sage Publications.

Holsti, R. (1969). Content Analysis for Social Science and Humanities. Massachussets: Addison Westly Publishing Company.

Hsieh, H.-F. (2005). Three Approaches to Qualitative Content Analysis. Qualitative Health Research, 15 (9), p.1277-1288. [Online]. Available at: doi:10.1177/1049732305276687.

Iliachenko, E. Y. (2005). Exploring Culture, History and Nature as Tourist Destination Branding Constructs: The Case of a Peripheral Region in Sweden. In: The VIII Nordic-Scottish Conference on Rural and Regional Development in association with the 14th Nordic Symposium in Tourism and Hospitality Research, 2005, Akureyri, p.1-11.

Kriyantono, R. (2007). Teknik Praktis Riset Komunikasi: Disertai Contoh Praktis Riset Media, Publik Relations, Advertising, Komunikasi Organisasi, Komunikasi Pemasaran. Jakarta: Kencana.

Littlejohn, S. W. and Foss, K. A. (2009). Teori Komunikasi: Theories of Human Communication. 9th ed. Jakarta: Salemba Humanika.

Morgan, N., Pritchard, A. and Pride, R. (2004). Destination branding: creating the unique destination proposition. 2nd ed. London: Butterworth-Heinemann Ltd.

Romli, A. S. M. (2012). Jurnalistik Online: Panduan Mengelola Media Online. Bandung: Nuansa Cendikia.

Situmorang, S. H. (2008). Destination Brand: Membangun Keunggulan Bersaing Daerah. Wahana Hijau: Jurnal Perencanaan \& Pengembangan Wilayah, 4 (2), p.79-86. [Online]. Available at: http://repository.usu.ac.id/handle/12345 $6789 / 17965$.

Suprapto, T. (2006). Pengantar Teori Komunikasi. Yogyakarta: Media Pressindo. 